\title{
Food Porn as Visual Narrative: Food Blogging and Identity Construction Gladys Koh
}

\section{Introduction}

Globalization has transformed the way modern society produces, prepares and consumes food. For the past twenty years, studies on the globalization of food have focused primarily on the effects of fast food industries on societies. The term "McDonaldization" was coined by sociologist George Ritzerin his seminal work "The McDonaldization of Society" (100-7). A decade later, the topic remains the same but the focus has shifted to the East with the popularity of eastern cuisine especially Japanese sushi in Western cultures (Carroll 451). Through the proliferation of fast food chains and sushi, new cultures of fusion food have emerged to diminish the social class differences in eating. However, there has been a revival in class-based eating in a recent phenomenon known as "food porn." Although it may sound outrageous, food porn is defined as "food that is so sensationally out of bounds of what a food should be that it deserves to be considered pornographic" (McBride 38). This refers to the mouthwatering, highly-stylized images of food displayed in magazines, cook shows and social media that is meant to induce the desire to eat. A key feature of food porn is its fantasy-like, unattainable quality, as most home cooks can never reproduce the exact dish presented. As noted by critic Richard Magee in "Food Puritanism", ornamental cooking is only valued for its attractive surface appearance, but is fully divorced from its taste or nutritional aspect (26-38). It is about putting on a show; a culinary performance to stimulate the sight of the audience and whet their appetites. The line between fiction and reality is often blurred in the visual representation of food. 
Today, food porn enjoys a boom in visibility thanks to the role of social media on the Internet. Food blogging is a popular outlet for individuals to share "their recipes, restaurant meals, opinions and food experiences in a public forum" (McGaughey69). Since its inception in 2002, food blogging has become a platform for the Internet-savvy generation to communicate and express their sense of identity. Blogs are personal websites containing texts, images, links and comments by readers. Blogs function as personal diaries but are openly accessible to the public sphere. Blogging fudges the boundaries between the professional and amateur, the private and public. It encourages "participative journalism" or "citizen journalism" (Haas 389) in which the average layman can log in to exchange information. This has led to the overlapping of journalism with non-professional writings (Lowrey 477-500). Food blogging falls into this category, with a rising number of self-proclaimed gourmets and experts in "foodie" culture. According to Andrew Cox and Megan Blake in their research on food blogging as a serious leisure, foodies "focus on the aesthetic and sensual appreciation of food as a form of claim to cultural distinction" (208). Social class anxieties seem to permeate the construction of identity by food bloggers. Most foodies are avid travelers with a sizable disposable income, but they are writing to an audience who comes from various socio-economic backgrounds. This has prompted researchers to suggest that food blogging is a search for self-identity and a desire for personal impact through sharing "skilled consumption" narratives with fellow bloggers who form "a community of consumption" (Watson et al. 295). Previous studies on food porn had all focused on the virtual interaction between food bloggers as a way of negotiating identity (Lynch 316-35; McGaughey 69-98). However, this paper will interpret identity using a semiotic approach. Although food blogging fever has gone viral in Malaysia and Singapore, there has been little research to date on the social significance of this internet phenomenon. This should not be so 
because certain food blogs such as Rasa Malaysia and Makansutra have gained status as national ambassadors of their respective countries.

The purpose of this paper is to examine the ways that self-identity and group identity are constructed by a Malaysian and a Singaporean food blogger through the visual narrative of food. A semiotic reading is offered using the images of food as an "anchor" to crystallize identity. With a focus on class-consciousness, I argue that food bloggers reproduce and reinforce ideologies promoting wealth, elegance, prestige, elitism and capitalist-consumerism. As a result,

the identity of food bloggers is synonymous with a narrative of affluence. To achieve a performance of glamour, they employ certain food photography techniques that create the "postcard effect" to satisfy the pleasure of the tourist gaze. I will analyze the deliberate framing of the tourist gaze in food blogs as a form of aggressive image advertising to represent identity. Finally, the social implications of food blogging will be discussed in detail. This study will lay the groundwork for future research on Southeast Asian food culture, thus contributing to the field of sociology, linguistics and media studies.

\section{Methods Data collection}

Due to the millions of food blogs floating in the World Wide Web, it is impossible to analyze all of them, so a criteria was required for selection. A sample of one Malaysian and one Singaporean food blog was chosen for case study: Bangsar Babe and Miss Tam Chiak. These two blogs have established a cult following and are featured in various publications such as newspapers, magazines and radio shows. Both bloggers are women in their late twenties who live in the city, have an independent career and enjoy eating and travelling for food. Bangsar Babe and Miss Tam Chiak were selected on the basis of i) variety: so as to represent a range of food types, 
recipes and food places ii) relevancy: the two blogs are actively updated at least once a week to ensure currency of post ii) consistency: both blogs are written in English and each food review is followed by accompanying photographs and food descriptions. Only blog entries from March to November 2013 for a period of eight months were analyzed for this study.

\section{Data analysis}

The overall layout and design of both blogs were first evaluated to ascertain the general atmosphere of the blogs. In particular, the blog headers were examined as a key section expressing the personality of the bloggers. Then images of food alongside their textual descriptions were decoded for their semiotic messages. Roland Barthes talked about "submitting the image to a spectral analysis of the messages it may contain" (32) in his agenda-setting work, "The Rhetoric of the Image." Using this approach, the connotative or ideological messages of food porn were analyzed by reading the signifiers arranged in a series of chronological photographs captured by the bloggers. Images of food functioned as an anchor to identity. According to Barthes in The Responsibility of Forms, anchoring is "a means of control, it bears a responsibility, confronting the projective power of the figures, as to the use of the message" (29). Food porn anchored the narrative of identity by crystallizing the ideology of the bloggers through visual metonymy. The metonymic images of food presented in bits and pieces throughout the blogs were read like comic strip narratives of the self. Fragments of these images were pieced together like a jigsaw puzzle to form the larger narrative representing the identity of the bloggers. Identity became a collage of "postcard" snapshots depicting food that was assembled together to construct the dominant narrative of the individual blogger.

The strategies that were used to produce the "postcard" effect of food were discussed. Using Laura Mulvey's theory of technology as visual pleasure and the notion of the tourist gaze, 
food porn was analyzed as a screen to project attitudes towards places and people which shape the self-image of the bloggers in the eyes of the public. The pleasure of the tourist gaze was gratified from the vicarious experience of watching graphic simulations of food and eating without being physically there. The impact of such indirect participation from the tourist gaze was summarized.

\section{Findings and Discussion Layout and design}

The sole author and mistress of Miss Tam Chiak is Maureen Ow, a Singaporean Chinese woman who began recording her gastronomic adventures in 2007. Her blog has a simple, basic layout with a plain white background which makes it easy to navigate for readers. A huge blog header displays rotating images of food which allows her visitors to feast their eyes on a variety of meals and drinks. These images are changed once every three days to keep things fresh. The title of her blog, "Miss Tam Chiak", is written in large font size 72 with a brief description that reads "Food. Travel. Photography." Everything in her blog is big - from the gigantic texts to the supersized pictures which occupy the centerspread (see fig. 1). Images of decadent food eclipsing the written text have the effect of focusing the reader's eyes on the food and glossing over the words, which seem less important. The blog design has an overall effect of being modern and minimalist in appearance. In the biography section, Maureen describes herself as "tam chiak", the Hokkien adjective for "greedy" as the language reflects her identity as a Singaporean Chinese. Although the blog was originally written in Chinese, she has changed the language to English for the convenience of her readers who are not proficient in Chinese. Maureen readily adapts her blog according to the needs of her audience and so negotiates her own identity through their feedback. Interestingly, she claims food blogging is a "serious hobby" and not a job. This creates the impression that she keeps a casual diary of what she eats on a 
daily basis. Furthermore, she distances herself from any food establishment by asserting that she is not a professional, which reinforces the idea of her being a casual food lover.

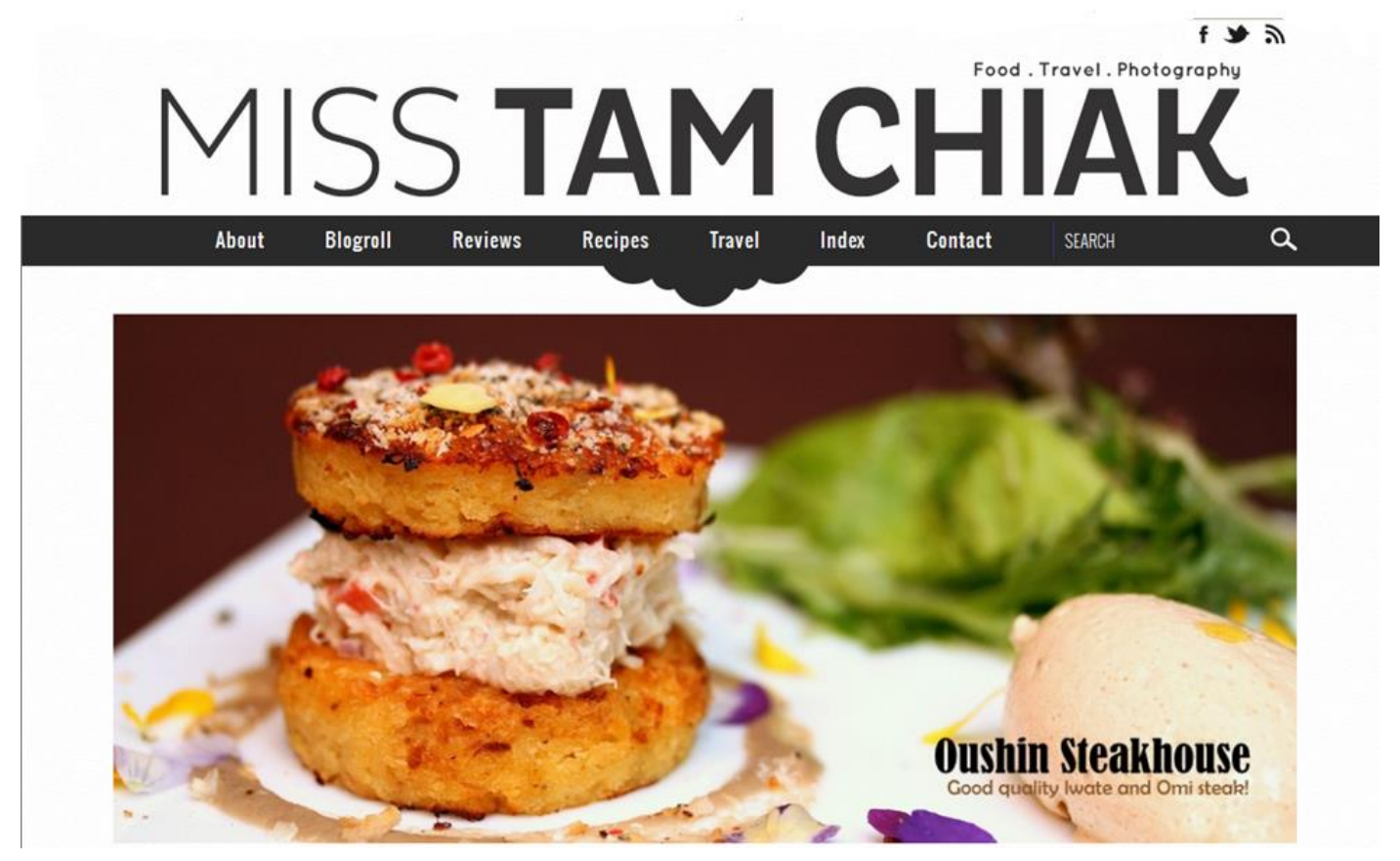

Fig. 1.Miss Tam Chiak's blog header from Ow, Maureen; "Homepage"; Miss Tam Chiak;n.d.; Web; 16 Nov. 2013.

In contrast, Bangsar Babe takes a more commercialized approach to blogging. The author is Tiong Sue Lyn, a Malaysian Chinese woman who is an ex-beauty pageant winner. Her blog is divided into three columns with multiple sections and links. The blog header shows a photo of her clad in a bikini beside the beach which rotates to display images of her dressed in branded clothing posing with handbags, shoes and accessories (see fig. 2). The motivation behind the blog header is to advertise her sponsors. Interestingly, the use of her body which functions as a model figure to display branded apparel suggests there is a homology between the human body and food. Both are consumer objects which serve as fashion statements, making fashion 
KOH 129

synonymous with food. There are also random advertisements placed across the site for foodrelated products. The title of the blog is derived from the author's place identity, as she has stayed in Bangsar since she was two years old. Originally a humble food diary in 2007, Bangsar Babe has expanded to include lifestyle posts. The intertwining of food porn, travel and fashion is made explicit in the blog. The author has also posted a series of images depicting her achievements in the media, including being crowned "Miss Popular" in Miss World Malaysia 2009.
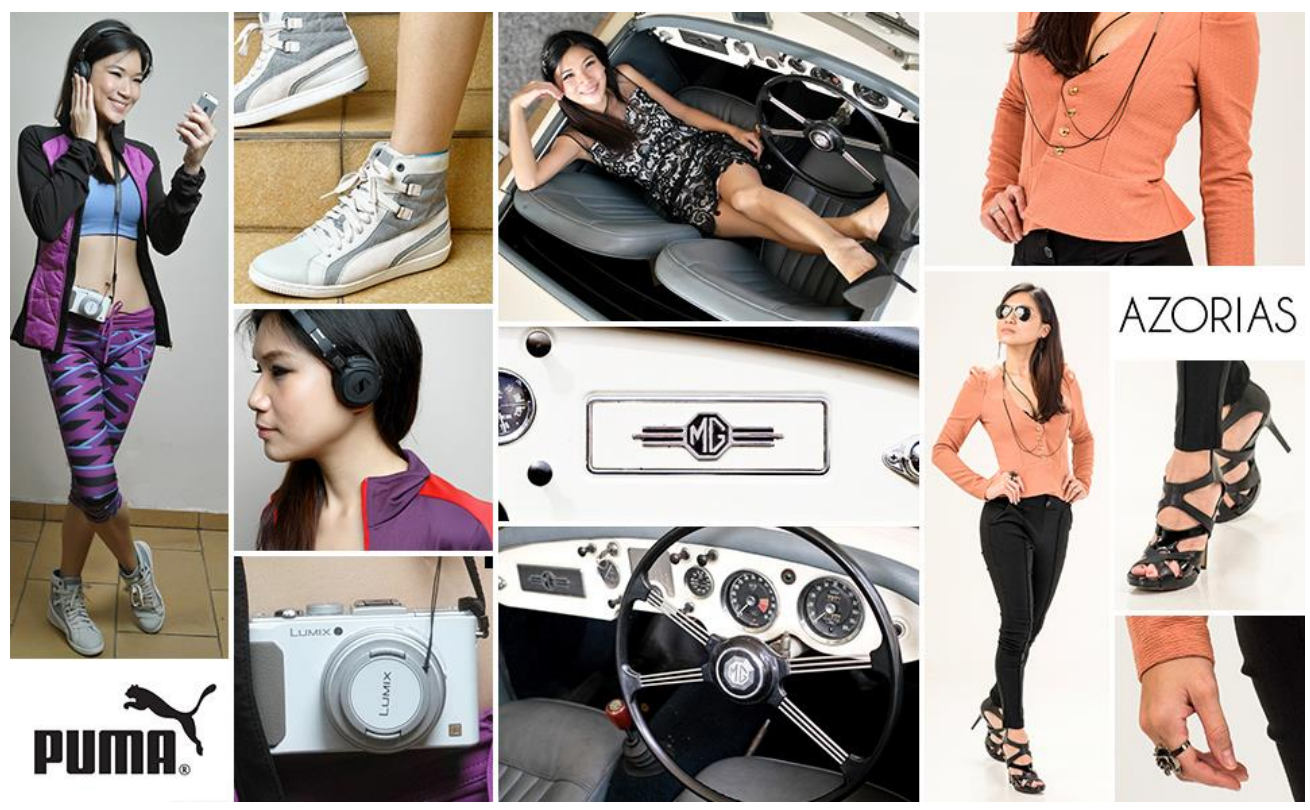

Fig. 2.Bangsar Babe's blog header from Tiong, Sue Lyn; "Homepage”, Bangsar Babe;n.d.; Web; 17 Nov. 2013.

The layout and design of Miss Tam Chiak and Bangsar Babe express two very different personalities. While the former identifies with a common dialect spoken by the Chinese community in Singapore, the latter identifies with a glamorous, upscale part of Kuala Lumpur which she calls her hometown. The distinctive approaches that they take in their blogs have a specific influence on the way foods are visualized in their works. 
$\mathrm{KOH} 130$

\section{Food porn}

The whole concept of Miss Tam Chiak revolves around the blogger's amazing photography skills. While her writings are brief and succinct, her food photos are bright, vivid and large so that they instantly grab the attention of the eyes. In a post entitled "The Seafood International Celebrates $30^{\text {th }}$ Anniversary with 30-Course Dinner" dated 16 October 2013, thirty seafood dishes were compiled into a colourful mosaic of spectacular images (see fig. 3). This mosaic served as a visual summary of what Maureen ate in a restaurant. They anchored her narrative of the dinner she enjoyed that night. She presented all thirty dishes in a chronological order, beginning with the appetizers, entrée, proceeding to the main courses and ending with desserts and free-flowing wine. More impressively, a choice of fine wines and liquors were displayed in a glass cabinet stuffed with ornamental grapes (see fig. 4). Seafood and wine is a rich combination that projects a cultured, metropolitan and sophisticated gourmet. Wine is a signifier that represents the intellectual and romantic qualities of the Europeans. 
$\mathrm{KOH} 131$

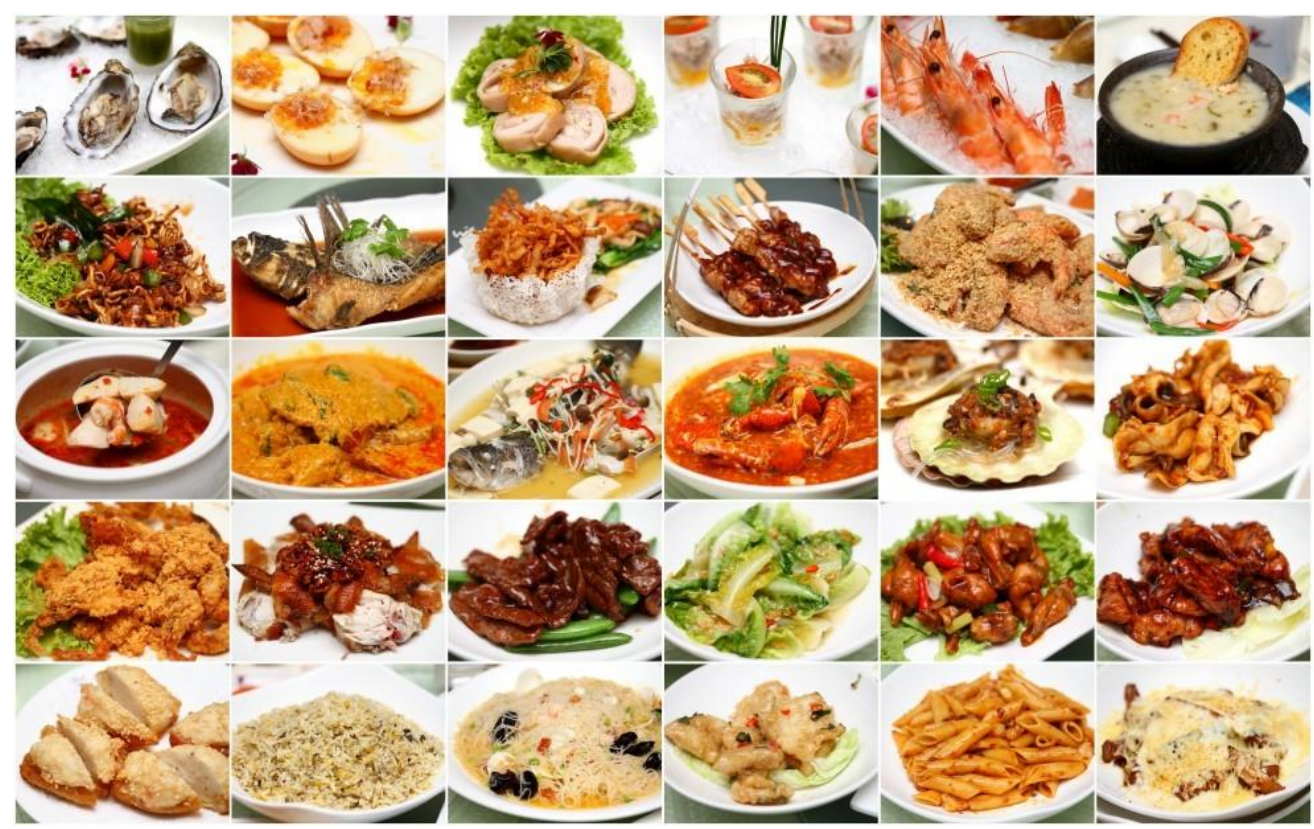

Fig. 3.The narrative of dinner from Ow, Maureen; "The Seafood International Celebrates 30 ${ }^{\text {th }}$ Anniversary"; Miss Tam Chiak; 16 Oct. 2013; Web; 15 Nov. 2013.

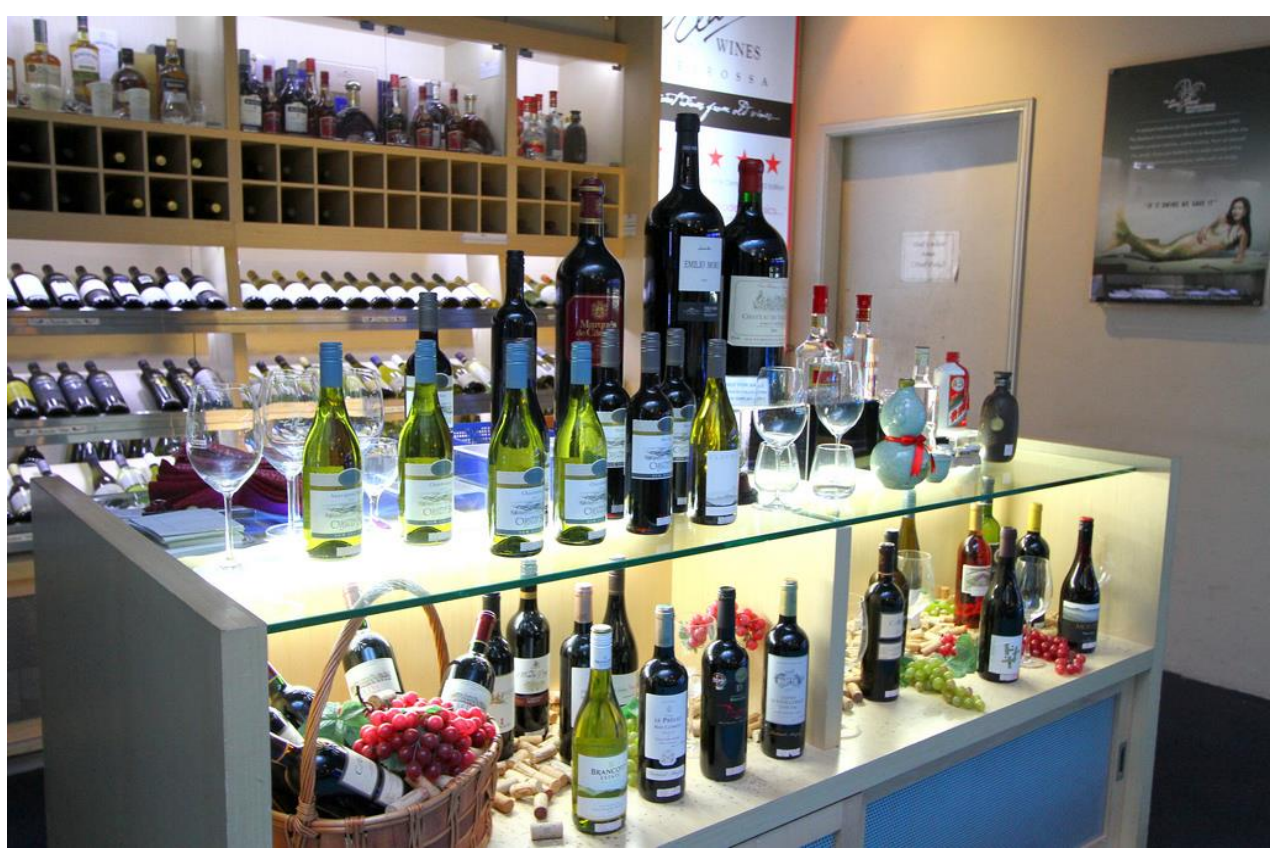

Fig. 4.Wine and liquor display from Ow, Maureen; "The Seafood International Celebrates 30 ${ }^{\text {th }}$ Anniversary"; Miss Tam Chiak; 16 Oct. 2013; Web; 15 Nov. 2013. 
$\mathrm{KOH} 132$

Maureen arranged her photos to follow a metonymic structure and pattern. Her food reviews typically begin with a picture of the venue she is dining in, a posh-looking bar, a hotel or a restaurant, then a step-by-step visual account of each meal she has tasted, before ending with a dessert or beverage. Venues play an essential role in constructing a narrative of elegance in her pictures, as an upscale-looking place connotes refined taste. In a post entitled "Penang Buffet at Princess Terrace, Copthorne King's Hotel" dated 5 August 2013, the author went to a Singaporean hotel to eat hawker food from Penang. An image of the hotel's interior with carpet, tables and soft lighting were first shown to set the atmosphere. Under the camera, something as common as Penang hawker food was cast in a new, seductive light. Foods such as Char Kuey Teow, Rojak, Laksa and Teh Tarik received a sensual, provocative portrayal. The camera zoomed in on the chunks of succulent prawns on noodles, blurring out the background details, and directing our gaze to the juicy meat. As a result, Penang hawker food becomes a lavish feast. Even unhealthy fast food was glorified as something exotic. Hamburgers were shown oozing with eggs and dripping with cheese. The author described them as "the sauciest, juiciest, tastiest bestest burgers around, the crispiest, freshest, hottest, bestest fries around and the chilliest, thickest, creamiest, bestest milkshakes around."(“Tripple O’s at Orchard Towers”, 3 Oct 2013). The over-the-top textual descriptions reinforced the message that only the blogger would have the privilege of eating the best burger in the world. It is special and unobtainable.

But the blogger's obsession with food goes beyond taste. There is a strong aesthetic appreciation of her meals and she goes to great lengths to display food artistically. In "Ezoca: Kaiseki Ryori", a collection of Japanese bowls were arranged on a tray like a modern art piece, while "Exquisite Dynasty Feast at Summer Palace, Regent Singapore" showed strips of abalone and mushrooms placed together to form a Chinese painting. This concern for beauty in food 
KOH 133

reflects the image of an individual who can afford to invest lots of time, energy and resources into pursuing culinary perfection. The author is constructing the narrative of a lady of leisure who spends her days consuming rare, exclusive foods in hotels and restaurants on an almost daily basis based on the frequency of her blog posts.

This identification with leisure extends to the domestic kitchen setting. Sometimes Maureen posts photos of her home cooking in her "Recipe" section. In "Recipe-Healthy Strawberry Parfaits" dated 8 October 2013, she showed a metonymic sequence of the process of making healthy parfaits. First, she displayed the fresh ingredients. Next, she posted a picture of cereals in a glass jar, followed by slices of strawberry embedded in yogurt. Finally, the finished parfait looked feminine in pink. Besides anchoring her gender identity through domesticity, Maureen used the "Recipe" section to identify her friends and relatives. The various images of her cooking dinner for Grandpa and baking birthday cakes for her friends merge to build a dominant narrative of a sweet, caring, filial, friendly, family-oriented and health-conscious Asian woman. Relationships with loved ones are explored through the medium of food: she lovingly prepares special dishes for friends and family. Her preoccupation with healthy eating also speaks volumes of her desire to take care of her body and this promotes the ideology of healthy living, which is a concern of the educated class.

Unlike her Singaporean counterpart, the Bangsar Babe is officially involved in the advertising and publishing industry. Sue Lyn's food photos contain a signature of her website, Bangsarbabe.com, for the purpose of trademark and copyright. Therefore, every image is labeled as intellectual property. Furthermore, each picture is uniquely attached to a caption which provides a textual description of it. As a brand ambassador, Sue Lyn is more likely to insert herself into the sequence of photographs when doing a food review. For example, in an entry 
called "King Cole Bar, the St. Regis Bali Resort" on 1 April 2013, the blogger was seen having tea in a luxury resort in Bali. The venue was exhibited with a caption that reads "Elegant and Sophisticated." The blogger herself is shown drinking a cup of tea in a white dress (see fig. 5). The caption credits her sponsor for the clothes. The photo was geared towards displaying fashionable clothing that matched the ambience of the café. In another post "Fine Dining at Kayuputi, St. Regis Bali" dated 24 April 2013, she is seen enjoying a glass of wine, then carrying a shopping bag while dressed in matching frock and hat. The insertion of Sue Lyn's physical self into her food pictures creates the narrative of a consumer "package" that is allinclusive. Dress, hat, shopping bag, café, wine and body are linked in a metonymic chain of signifiers. The ideology of a modern hedonistic lifestyle is crystallized through

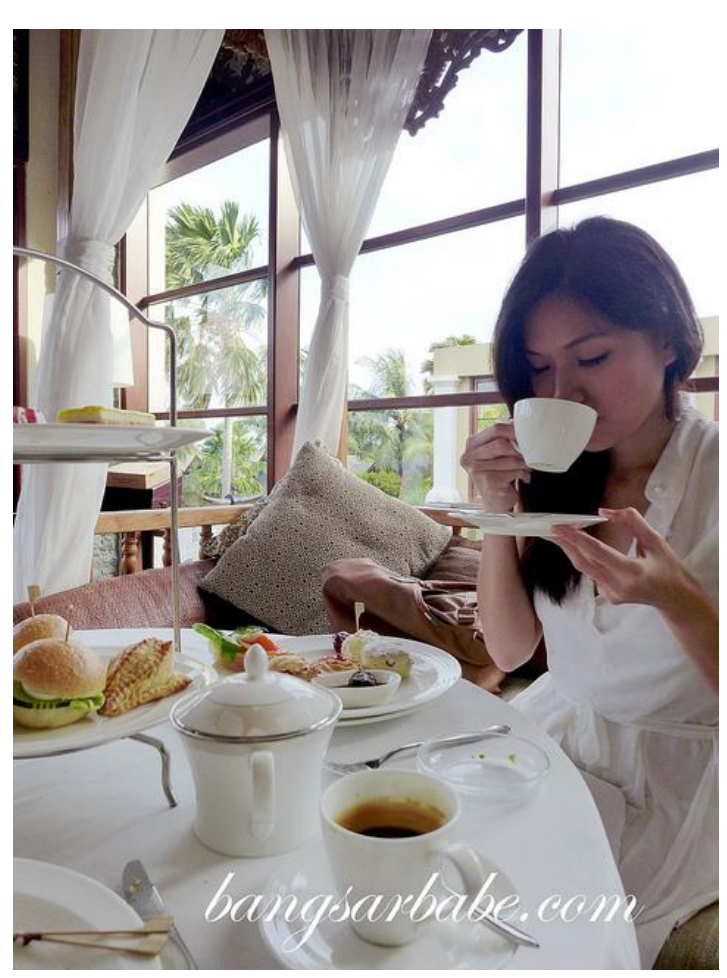
the image.

Fig. 5.The blogger's tea time from Tiong, Sue Lyn; "King Cole Bar, the St. Regis Bali Resort”; Bangsar Babe; 1 Apr. 2013; Web; 17 Nov. 2013. 
$\mathrm{KOH} 135$

Moreover, the abundance of food and the freedom to indulge are expressed in her post, "Yard of Sausage Challenge at Gastro", where she joined an eating competition in September 2013. She is portrayed smiling above a giant sausage filled with nacho cheese with a caption that reads "Challenge accepted!" (see fig. 6). Readers can see the sheer amount of food available as posing a difficulty to the author. Next a series of photos show her eating more than 1kilogram of sausages and a pound of fries. It is considered a gastronomic feat worthy of admiration. The message conveyed is that of adventure, fun, daring, success and achievement. These are the qualities readers perceive as embodied by the blogger. They are the same qualities that the readers aspire towards. Besides that, she identifies her spouse as helping her to finish the meal, thus tying in the concept of family with eating. The frequent naming of relatives and friends who participate in her food hunts projects a sociable and family-oriented image. Food is viewed as an extension of the self and self in relation to community.

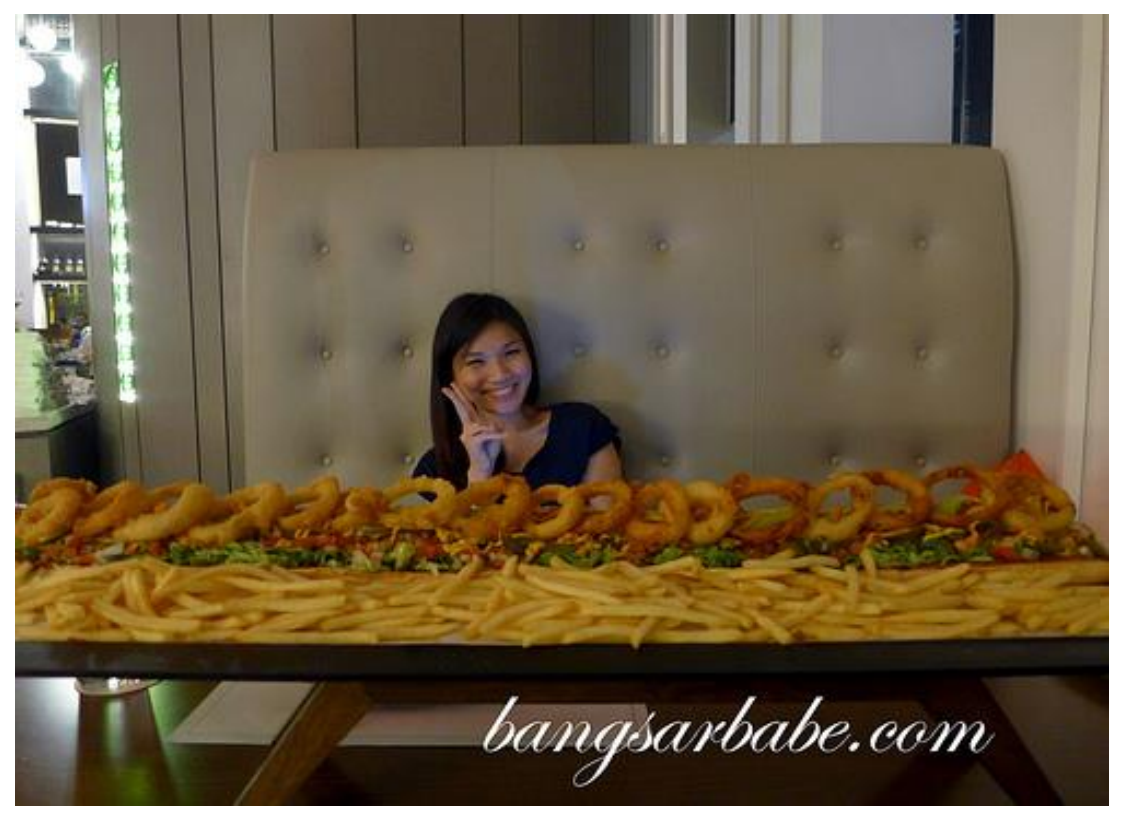

Fig. 6.Sausage eating competition from Tiong, Sue Lyn; "Yard of Sausage Challenge at Gastro";Bangsar Babe; 9 Sept. 2013; Web; 17 Nov. 2013. 
However, the author wrote about facing pressure from her audience to continue reviewing food. Responding to a feedback by a disappointed reader, she decided to satisfy his demands by posting a series of food images in "Random food updates," 6 September 2013. The photos supposedly depict what she ate for the past two weeks: Mediterranean seafood, wine, dessert, kimchi, pasta and latte. The author was careful to select an assortment of hybrid, upscale food that represents a global tastebud. The performative aspect of her pictures reflects the blogger's identity as an idol who entertains her audience with food. Thus a celebrity-fan relationship is enacted between the blogger and her readers through this performance of glamour.

\section{The Tourist Gaze}

The gaze of the tourist is characterized by a simulated experience of visiting a place without engaging the self in the real political or cultural complexities of the place (Sadler and Haskins 195). In Bangsar Babe, the author maps out her foodie adventures according to location, compressing the realities of Malaysia as a country into a collage of postcard food images. The narrative of Malaysia as an exotic melting pot is firmly anchored in the visuals of hybrid food presented. Most importantly, she directs the tourist gaze to a unique aspect of Malaysia which is street food culture. Sue Lyn often reveals obscure food stalls that are known only to the locals living in that area, therefore assuming the role of a native informant. No food is too humble to be blogged about. She goes so far as to introduce "mixed economy rice" found in the section of Kuala Lumpur called Pudu so that readers, put in the position of tourists, can experience honest, "authentic" Malaysian food by looking at her photos. The myth of authenticity is a driving force 
behind her blog. However, even in the midst of presenting street food, the sequence of food images is sometimes interrupted with pictures of the blogger posing in fashionable clothing.

Conversely, Miss Tam Chiak makes use of the author's advanced photographic skills to craft the narrative of Singapore as a modern, clean, progressive and attractive destination. She achieves this by letting her camera linger on images of clean streets, green sceneries, posh bars, elegant hotels, modern infrastructure and orderly shopping malls. Only these positive aspects of the city are captured by her lens. The effect is similar to gazing at a pure and pristine Singapore. All these pictures are included as part of her food reviews. The emphasis on buildings and venues in her food posts provide an opportunity to showcase the development of her city. For example, an entry headlined "Brunch at GRUB, Bishan Park" on 13 September 2013 narrates Maureen's experience of visiting a park for a meal. She displays photos of lush greenery, trees and flowers planted neatly (see fig. 7). This scenery anchors the message of an environmentfriendly Singapore that preserves nature. Finally, she includes a picture of an adorable pet dog with clean, well-groomed fur standing in the park. This projects the myth of a warm, friendly, and animal-loving neighbourhood. The tourist gaze, directed by the camera lens, is able to experience her food journey in the park vicariously through the metonymic sequence of photos. The blogger's photography actively constructs Singapore and creates a tourist-friendly narrative filled with a nationalist agenda. 
$\mathrm{KOH} 138$

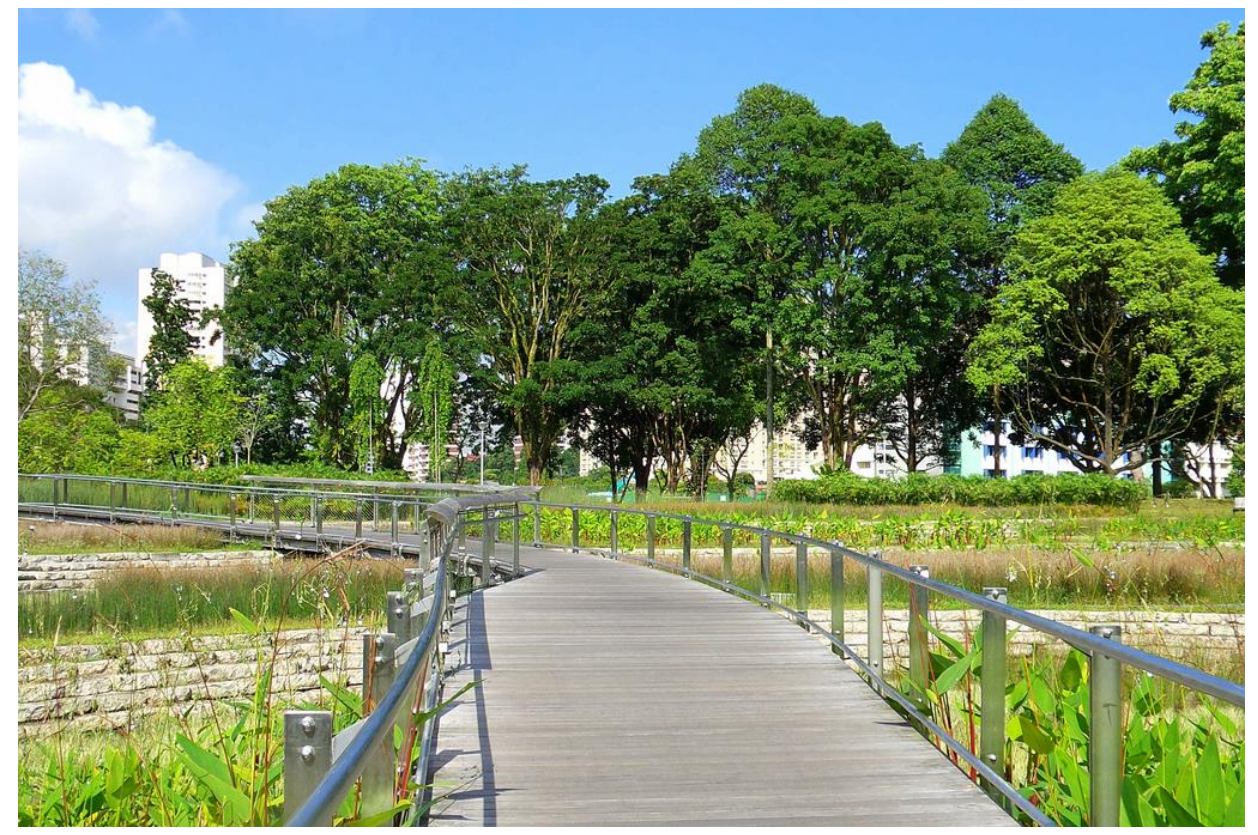

Fig. 7. Journey across the park from Ow, Maureen; "Brunch at GRUB, Bishan Park";

Miss Tam Chiak; 13 Sept. 2013; Web; 15 Nov. 2013.

\section{Conclusion}

The concept of the blog as a rotating billboard that displays identity has led to the birth of food porn as a form of aggressive self-image marketing. Bloggers compete to turn images of food and themselves into postcards so that they can attract the attention of consumers which, in turn, generates revenue. It does not matter if these images are genuine or faithful copies of the original. All that matters is that they need to be visually persuasive enough to instill the desire to consume. In the words of James Donald, "what matters about myth and magic is not their truth, but their effectiveness" (Visual Culture79). To be effective, pictures of food may need to undergo a process of photo editing and other visual manipulations using technology. 
On the surface, it seems, both Miss Tam Chiak and Bangsar Babe are highly personalized food blogs expressing the individuality of two female bloggers. Each blogger constructs a supposedly unique narrative of the self via the medium of food photography. However, in reality, it is not clear where and when the self begins, and where the myth of consumerism begins as there is a very porous, slippery boundary between fact and fiction in the virtual realm. It is also not clear if the freedom and empowerment that is expressed through the blogger's personality cult in choosing what to eat is merely an illusion. In the blogosphere, identity has become a cult, and like any other cult, it needs a set of myths to anchor in its ideology of smart living. Sensational images of food serve as that anchor for what is perceived as the dream lifestyle that most readers aspire towards. A sequence of images synthesizing food with cities, people, fashion, and other consumer products are presented as "natural." From the luxury restaurants right down to the succulent, juicy meals and branded handbags there is the consistent message that the bloggers are living the high-flying life of a successful young urban professional. The relationship between the bloggers and food images then, is that of a cult and myth. The former is an embodiment of consumerist-capitalist values. The latter justifies it as right and natural.

A number of implications have arisen from this study. Firstly, although globalization has been said to eradicate class differences in eating, the practice of food blogging has merely reintroduced and reinforced class-consciousness in the readers. Food porn is bourgeoisie art peddling the fantasy of high living to the masses. There is also the illusion of freedom of choice and the sense of empowerment from consuming such food images when all it boils down to is the idea of marketability. On the pretext of expressing their individuality, bloggers will only present the most visually appealing meals to the readers, thus limiting options and shaping a demand for these foods. Secondly, there are ethical and moral concerns regarding the role of 
KOH 140

food bloggers as figures of celebrity and authority with the power to influence the eating decisions of the public, especially that of the younger generations. As the self-appointed gatekeepers of gourmet culture, bloggers needs to be held accountable for spreading information which gets passed on as facts. Finally, the distance between people and food consumption is growing wider and wider. Eating is no longer a spontaneous activity, but done through the indirect, vicarious experience of watching graphic simulations of food. Modern society is being increasingly alienated by technologies of visual pleasure which erode the eating experience itself.

Considering the findings of this study, more research needs to be done in future regarding the effects or consequences of absorbing food porn ideology over a certain length of time. A quantitative survey should be done to identify the type of netizens who are most likely to be food porn addicts and the amount of time or frequency spent gazing at these images. Specifically, there is an urgent need to educate the public regarding the unconscious implications behind the seemingly innocuous practice of food blogging.

\section{Works Cited}

Barthes, Roland. "Rhetoric of the Image".Image-Music-Text.Trans. Stephen Heath. New York: Hill \& Wang, 1977.32-51. Print.

Barthes, Roland. The Responsibility of Forms: Critical Essays on Music, Art, and Representation. Berkeley:U of California P, 1991. Print.

Carroll, Walter F. "SUSHI: Globalization Through Food Culture: Towards a Study of Global Food Networks.”東アジア文化交涉研究 2 (2009): 451-56. Print. 
$\mathrm{KOH} 141$

Cox, Andrew M., andMegan K. Blake."Information and Food Blogging as Serious Leisure." Aslib Proceedings 63. 2/3 (2011): 204-20. Emerald Insight.Web. 8 Dec. 2013.

Donald, James. "The City, the Cinema: Modern Spaces." Visual Culture. New York: Routledge, 1995. 77-95. Print.

Haas, Tanni. "From "Public Journalism" to the "Public's Journalism"? Rhetoric and Reality in the Discourse on Weblogs.”Journalism Studies 6.3 (2005): 387-96.Taylor \& Francis Journals. Web. 8 Dec. 2013.

Kerr, Gayle, et al. "Buy, Boycott or Blog: Exploring Online Consumer Power to Share, Discuss and Distribute Controversial Advertising Messages.”European Journal of Marketing 46.3/4 (2012): 387-405.Emerald Insight.Web. 8 Dec. 2013.

Lowrey, Wilson. "Mapping the Journalism-Blogging Relationship."Journalism 7.4 (2006): 477500.SAGE Journals. Web.8 Dec. 2013.

Lynch, Megan. "Healthy Habits or Damaging Diets: An Exploratory Study of a Food Blogging Community."'Ecology of Food and Nutrition 49.4 (2010): 316-35.Taylor \& Francis Journals. Web.10 Dec. 2013.

Magee, Richard. "Food Puritanism and Food Pornography: The Gourmet Semiotics of Martha and Nigella." The Journal of American Popular Culture6 (2007): 26-38.Americana. Web. 10 Dec. 2013.

McBride, Anne E. “Food Porn.”Gastronomica: The Journal of Food and Culture, 10(1), 38-46. JSTOR.Web.10 Dec. 2013.

McGaughey, Kerstin. "Food in Binary: Identity and Interaction in Two German Food Blogs." Cultural Analysis 9 (2010): 69-98.Socrates. Web. 8 Dec. 2013. 
$\mathrm{KOH} 142$

Mulvey, Laura. Visual and Other Pleasures. London: Macmillan, 1989. Print.

Ow, Maureen. "Brunch at GRUB, Bishan Park."Miss Tam Chiak. Maureen Ow, 13 Sept. 2013.

Web. 15 Nov. 2013.<http://www.misstamchiak.com/brunch-at-grub-bishan-park/>.

Ow, Maureen. “Exquisite Dynasty Feast at Summer Palace, Regent Singapore.”Miss Tam Chiak. Maureen Ow,7 Oct. 2013. Web. 15 Nov. 2013.<http://www.misstamchiak.com/ exquisite-dynasty-feast-at-summer-palace-regent-singapore/>.

Ow, Maureen. “Ezoca - The Art of KaisekiRyori."Miss Tam Chiak. Maureen Ow, 9 Oct. 2013.

Web. 15 Nov. 2013. <http://www.misstamchiak.com/ezoca-the-art-of-kaiseki-ryori/>.

Ow, Maureen. "Recipe - Healthy Strawberry Parfaits."Miss Tam Chiak. Maureen Ow, 8 Oct. 2013. Web. 15 Nov. 2013. <http://www.misstamchiak.com/recipe-healthy-strawberryparfaits/>.

Ow, Maureen. "Penang Buffet at Princess Terrace, Copthorne King's Hotel (Plus Giveaway)." Miss Tam Chiak. Maureen Ow, 5 Aug. 2013. Web. 15 Nov. 2013. <http://www.misstamchiak.com/penang-buffet-at-princess-terrace-copthorne-kingshotel/>.

Ow, Maureen. "The Seafood International Celebrates $30^{\text {th }}$ Anniversary with 30-Course Dinner." Miss Tam Chiak. Maureen Ow, 16 Oct. 2013.Web. 15 Nov. 2013. <http://www.misstamchiak.com/the-seafood-international-celebrates-30th-anniversarywith-30-course-dinner/>.

Ow, Maureen. “Tripple O’s @ Orchard Towers - This Canadian Burger Chain is Even Older thanMcdonald's!" Miss Tam Chiak. Maureen Ow, 15 Nov. 2013. <http://www.misstamchiak.com/triple-os-orchard-towers/>.

Ritzer, George. "The "McDonaldization" of Society."Journal of American Culture 6.1 (1983): 100-107.Wiley Online Library. Web.10 December 2013. 
Sadler, William J., and Ekaterina V. Haskins. "Metonymy and the Metropolis: Television Show Settings and the Image of New York City."Journal of Communication Inquiry, 29.3 (2005): 195-216.SAGE Journals.Web. 8 December 2013.

Tiong, Sue Lyn. "Fine Dining at Kayuputi, St Regis Bali Resort.”Bangsar Babe. Bangsar Babe, 24 Apr. 2013. Web. 17 Nov. 2013. <http://bangsarbabe.com/2013/04/ kayuputi-st-regis-bali-resort.html>.

Tiong, Sue Lyn.“King Cole Bar at St Regis Bali Resort.”Bangsar Babe.Bangsar Babe, 1 Apr. 2013. Web, 17 Nov. 2013. <http://www.bangsarbabe.com/2013/04/ king-cole-bar-st-regis-bali-resort.html>.

Tiong, Sue Lyn. "Random Food Updates.”Bangsar Babe.Bangsar Babe, 6 Sept. 2013. Web. 17 Nov. 2013. <http://www.bangsarbabe.com/2013/09/random-food-updates.html>. Tiong, Sue Lyn. "Yard of Sausage Challenge at Gastro."Bangsar Babe.Bangsar Babe, 9 Sept. 2013. Web. 17 Nov. 2013. <http://www.bangsarbabe.com/2013/09/ gastro-sentral-sausage-challenge.html>.

Watson, Pamela, et al. "Online Communities and the Sharing of Extraordinary Restaurant Experiences." Journal of Foodservice 19.6 (2008): 289-302.Wiley Online Library.Web. 10 December 2013. 